\title{
RESEARCH AND PRACTICAL TRENDS IN GEOSPATIAL SCIENCES
}

\author{
A. P. Karpik, I. A. Musikhin \\ Siberian State University of Geosystems and Technologies, 10, Plakhotogo Str., Novosibirsk, 630108, Russian Federation - \\ igor_musihin@mail.ru
}

Special Session, SpS 8

KEY WORDS: Research and Practical Trends, Geospatial Sciences, Analysis, Emerging Markets

\begin{abstract}
:
In recent years professional societies have been undergoing fundamental restructuring brought on by extensive technological change and rapid evolution of geospatial science. Almost all professional communities have been affected. Communities are embracing digital techniques, modern equipment, software and new technological solutions at a staggering pace. In this situation, when planning financial investments and intellectual resource management, it is crucial to have a clear understanding of those trends that will be in great demand in 3-7 years. This paper reviews current scientific and practical activities of such non-governmental international organizations as International Federation of Surveyors, International Cartographic Association, and International Society for Photogrammetry and Remote Sensing, analyzes and groups most relevant topics brought up at their scientific events, forecasts most probable research and practical trends in geospatial sciences, outlines topmost leading countries and emerging markets for further detailed analysis of their activities, types of scientific cooperation and joint implementation projects.
\end{abstract}

\section{INTRODUCTION}

Permanent and rapid evolution and diversity of science and technology makes us take a stop and then jump forward in the future to have a look backwards for a better understanding of which of the current and advanced tendencies will be in use in 5 or 7 years from now. In this line it is essential to have a clear assessment procedure allowing us to understand which of the technologies and scientific fields the society concentrates its intellect and forces at present will be in great demand at that time, as well as to find out the spheres for efficient actions to be done in the nearest future.

For this purpose it was decided to analyze the current scientific research, review and practical papers presented at the congresses, conferences, working weeks, and workshops of several well-known non-governmental international organizations, published from 2009 to 2014. As a rule, the missions of these organizations are dedicated to the development of an active international cooperation for the advancement of knowledge, research, development, education and training in spatial sciences, their integration and applications to contribute to the well-being of humankind and the sustainability of the environment. Due to the fact that both current research and practical activities incorporate areas of different sciences dealing with acquisition, analysis, processing, storage, integration, and visualization of spatial information in our study we investigated all of the theoretical, practical, and review papers published at the congresses and other scientific events of such international organizations as International Federation of Surveyors (FIG), International Cartographic Association (ICA), and International Society for Photogrammetry and Remote Sensing (ISPRS).

The results of the analysis gave us some ideas about:

1. Topmost scientific subject domains which lie in the area of interests of the professional societies

2. A number of leading countries that make major contribution in research and implementation of advanced practices both in the field of geospatial sciences (GS) and other sciences related to GS

3. The number of the countries, presenting innovation technologies and research, that can be considered as potential partners in future research and project activities

4. The external emerging markets for the development of international cooperation

5. A list of national research and development centres and institutions whose work and experiences should be studied and analyzed properly, and then taken into consideration for planning one's own activities.

For this study we used such research tools as target group surveys and interviews; analysis of the 2009 - 2014 scientific works published at the FIG, ICA, and ISPRS congresses, working weeks and conferences; analysis of national institutions, planning, research and production cycles, websites.

In this paper we will describe only the results of our study concerning scientific activities of FIG, ICA, and ISPRS, leaving the rest of received information beyond the scope of this work.

\section{INTERNATIONAL FEDERATION OF SURVEYORS}

FIG is a recognized non-governmental organization of national member associations that covers the whole range of professional fields within the global surveying community. It represents more than 120 countries throughout the world. The aim of the Federation is to ensure that the disciplines of surveying and all who practice them meet the needs of the markets and communities that they serve. FIG provides an international forum for discussion and development aiming to promote professional practice and standards. From this point of view it was quite interesting to study current activities applied by professionals in their everyday life.

FIG's technical work is led by ten commissions whose terms of reference are as follows: Professional Practice, Professional Education, Spatial Information Management, Hydrography, Positioning and Measurement, Engineering Surveys, Cadastre 
and Land Management, Spatial Planning and Development, Valuation and the Management of Real Estate, Construction Economics and Management.

Major element, providing successful work of FIG Commissions, is the human resource capacity building and resources of their members, representing national professional federations, associations and societies. This fact allows FIG to organize and hold its annual events at a very high level in terms of organization, as well as practical and scientific content.

Within our study we analyzed the FIG materials published at:

- FIG Congress in Kuala Lumpur, Malaysia, 2014 - 358 papers

- FIG Working Week in Abuja, Nigeria, 2013 - 124 papers

- FIG Working Week in Rome, Italy, 2012 - 329 papers

- $8^{\text {th }}$ FIG Regional Conference in Montevideo, Uruguay, 2012 79 papers.

Based on the results of our analysis we managed to mark out the most mentioned topics in the field of development and use of advanced techniques, devices, tools, and software.

The study of the topics enabled us to group them into fourteen major subgroups, describing current topmost practical and scientific interests, see Table 1.

\begin{tabular}{|c|c|c|}
\hline No & $\begin{array}{l}\text { Most popular subgroups of topics, } \\
\text { brought up at FIG events from } 2012 \text { to } \\
2014\end{array}$ & Percentage \\
\hline 1 & $\begin{array}{l}\text { Cadastre: reforms, systems, innovation, } \\
\text { administration, 3D and 4D cadastre, } \\
\text { taxation, rights }\end{array}$ & 36.4 \\
\hline 2 & $\begin{array}{l}\text { GNSS: precise point positioning, } \\
\text { applications, spatial data infrastructure, } \\
\text { multi-sensor systems }\end{array}$ & 11.6 \\
\hline 3 & $\begin{array}{l}\text { Applied geodesy: professional standards } \\
\text { and practices, tools and methods }\end{array}$ & 9.7 \\
\hline 4 & $\begin{array}{l}\text { Laser scanning: techniques and } \\
\text { applications, 3D modelling, remote } \\
\text { sensing, BIM }\end{array}$ & 8.1 \\
\hline 5 & $\begin{array}{l}\text { Hydrography: planning, environment, } \\
\text { water resources management }\end{array}$ & 6.3 \\
\hline 6 & $\begin{array}{l}\text { Web-GIS and GIS: mapping, GIS } \\
\text { algorithms and techniques, maps and new } \\
\text { trends in cartographic products }\end{array}$ & 5.5 \\
\hline 7 & $\begin{array}{l}\text { Professional education: teaching } \\
\text { methods, retraining }\end{array}$ & 5.4 \\
\hline 8 & $\begin{array}{l}\text { Spatial algorithms and techniques, spatial } \\
\text { data processing }\end{array}$ & 4.9 \\
\hline 9 & Deformation monitoring, geodynamics & 4.1 \\
\hline 10 & Global networks & 2.5 \\
\hline 11 & $\begin{array}{l}\text { Geodetic methods for studying climate } \\
\text { change }\end{array}$ & 1.8 \\
\hline 12 & Gravity field: geoid, heights & 1.6 \\
\hline 13 & UAV in geodesy, remote sensing data & 1.4 \\
\hline 14 & Electronic management systems & 0.6 \\
\hline
\end{tabular}

Table 1. Frequency of publications devoted to particular topics in the FIG materials 2012-2014

Since FIG represents professional practices and experiences, the next step of our analysis was to find out those countries that make major contribution in implementation and research of the marked out subgroups, see Figures 1-8.

Due to the fact that the topics of subgroups 10,11, 13 and 14 were brought up by just certain professionals and scientists representing various countries, it was difficult to mark out the leading countries. In this regard it is possible to make an assumption that here we can speak about:
New trends that have not received wide distribution among specialists yet, but may become very popular in future Trends losing their relevance

Trends that need advanced material base and further investigation.

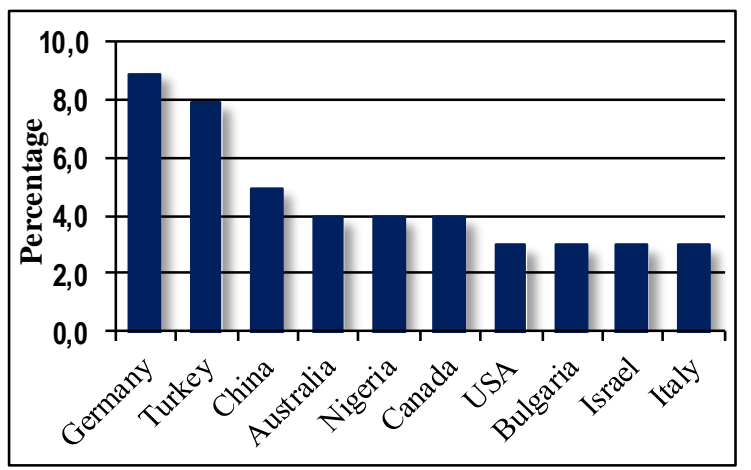

Figure 1. Countries making major contribution in implementation and research related to GNSS: precise point positioning, applications, spatial data infrastructure, multi-sensor systems

We also did not analyse subgroup 7 (Professional education: teaching methods and retraining) in view of the fact that it was beyond the scope of our study.

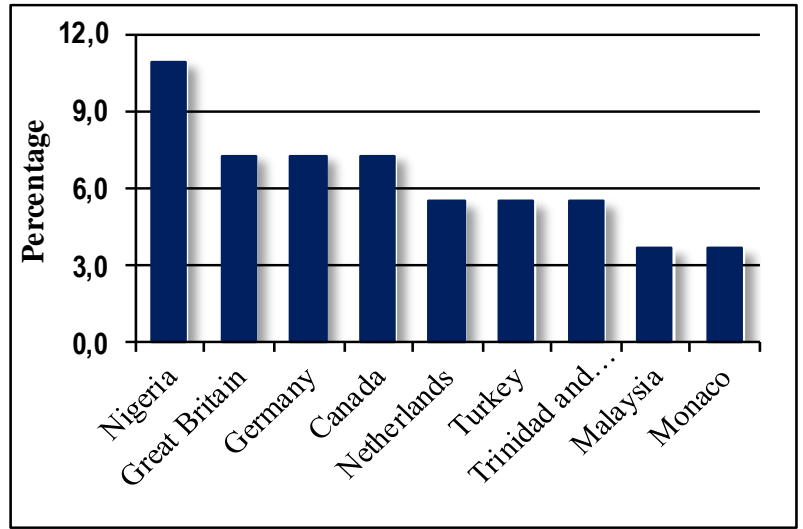

Figure 2. Countries making major contribution in implementation and research related to Hydrography: planning, environment, water resources management

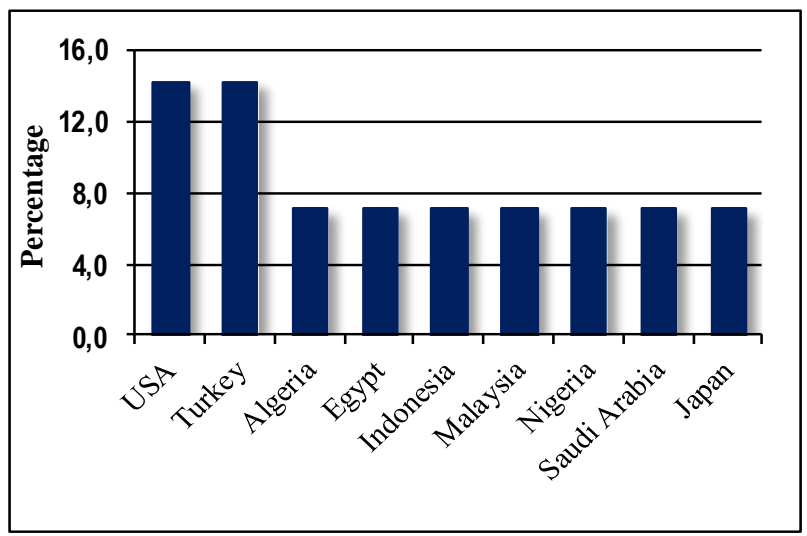

Figure 6. Countries making major contribution in implementation and research related to Gravity Field: geoid, heights 
While analyzing metadata on leading countries of the marked out subgroups we noticed a clear correlation between the place of an FIG event and a large number of papers presented by the local professionals and scientists. Thus, the obtained results may not form a clear view, concerning such countries as Malaysia, Nigeria, Italy, and Uruguay.

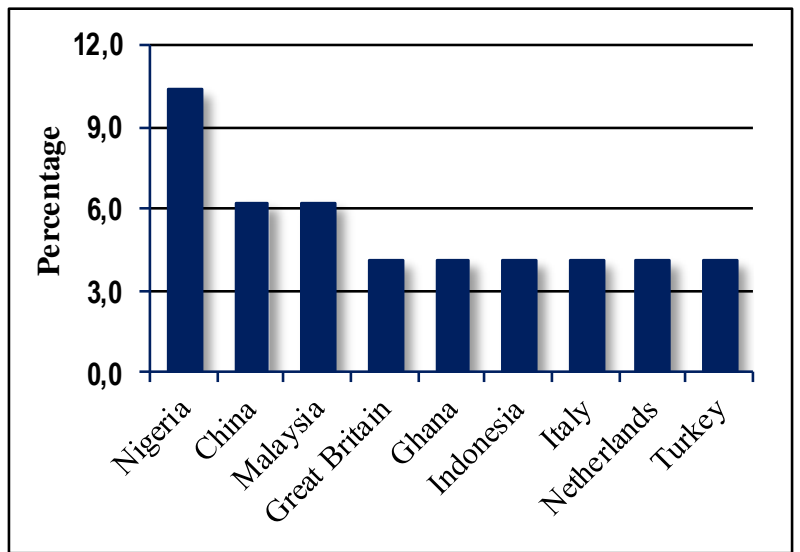

Figure 3. Countries making major contribution in implementation and research related to Web-GIS and GIS: mapping, GIS algorithms and techniques, maps and new trends in cartographic products

The carried out analysis of the FIG publications, devoted to current needs and practices, allows drawing the most likely scenarios that may take place in the development of geodesy in the nearest future:

1. Further development of GIS

2. Development and integration of different GNSS

3. Wide use of crowdsourcing and open-source software for data processing

4. Considerable changes in traditional approaches used in geodesy (geodetic survey) with tendency shift towards multi-sensor systems, remote sensing, UAV, on-line data exchange and processing

5. Automated processing of geodetic observations

6. Special attention will be paid to the development of general approaches, techniques, and applications to solve problems and satisfy needs of the first subgroup, see Table 1 .

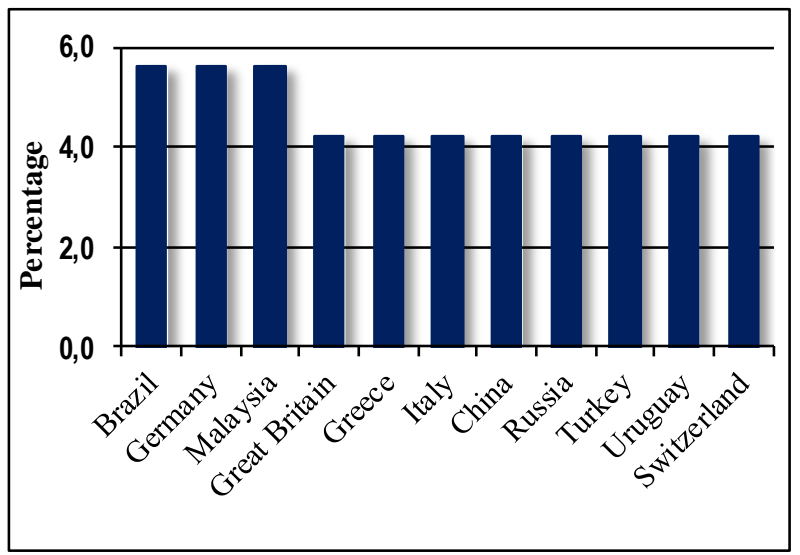

Figure 4. Countries making major contribution in implementation and research related to Laser scanning: techniques and applications, 3D modelling, remote sensing, BIM
7. Emergence of specialized personnel training and retraining centers providing life-long training.

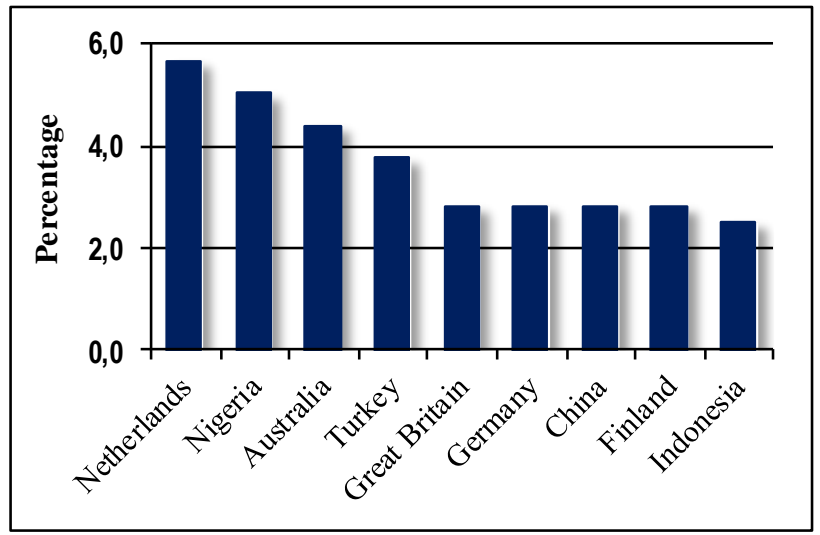

Figure 5. Countries making major contribution in implementation and research related to Cadastre: reforms, systems, innovation, administration, 3D and 4D cadastre, taxation, rights

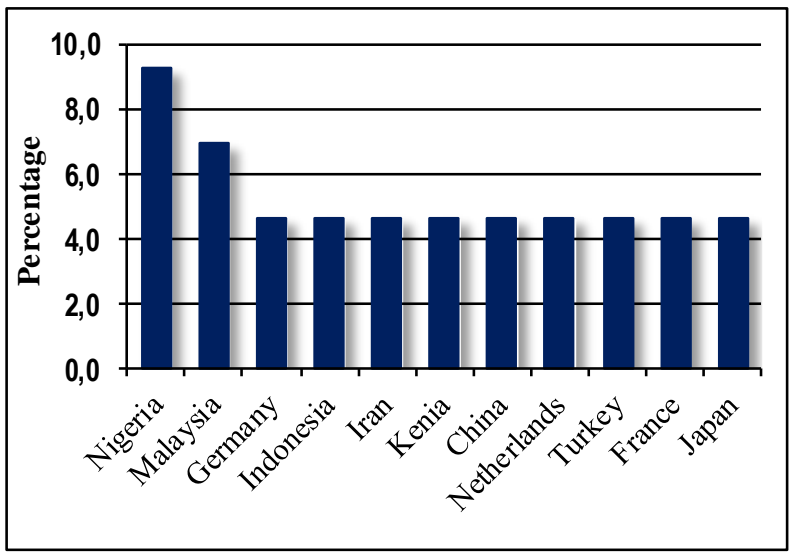

Figure 7. Countries making major contribution in implementation and research related to Spatial Algorithms and Techniques, Processing of Spatial Data

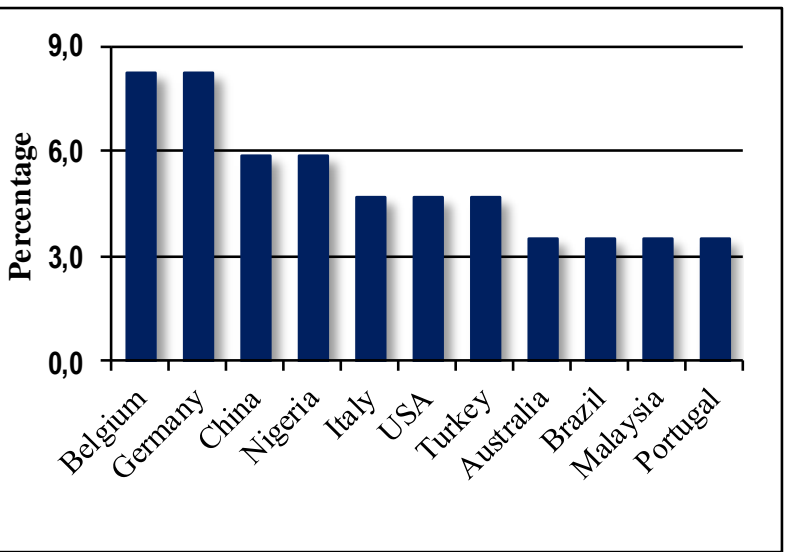

Figure 8. Countries making major contribution in implementation and research related to Applied Geodesy: professional standards and practices, tools and methods 


\section{INTERNATIONAL CARTOGRAPHIC ASSOCIATION}

International Cartographic Association is a non-governmental organisation that was founded in 1959. ICA promotes the development of cartography and related sciences; covers coordination and carrying out cartographic research requiring international cooperation. The Association provides international discussion platforms for scientists and professionals enabling professional society to exchange experience and advanced achievements in cartography.

Presently 77 countries are the members of ICA. Apart from that ICA has close relations with international governmental and commercial bodies, as well as other international scientific nongovernmental organizations.

ICA's technical work is led by 27 commissions:

1. Art and Cartography

2. Atlases

3. Cartographic Heritage into the Digital

4. Cartography and Children

5. Cartography in Early Warning and Crisis Management

6. Cognitive Issues in Geographic Information Visualization

7. Education and Training

8. Generalization and Multiple Representation

9. Geospatial Analysis and Modelling

10. GI for Sustainability

11. History of Cartography

12. Location Based Services

13. Map Design

14. Map Production and Geoinformation Management

15. Map Projections

16. Maps and Graphs for Blind and Partially Sighted People

17. Maps and the Internet

18. Mountain Cartography

19. Open Source Geospatial Technologies

20. Planetary Cartography

21. SDI and Standards

22. Sensor-driven Mapping

23. Topographic Mapping

24. Toponomy

25. Ubiquitous Mapping

26. Use, User and Usability Issues

27. Visual Analytics.

Within our study we analyzed the ICA materials published at:

- 24th International Cartographic Conference, Santiago, Chile, 2009 - 213 papers

- 25th International Cartographic Conference, Paris, France, 2011 - 298 papers

- $26^{\text {th }}$ International Cartographic Conference, Dresden, Germany, 2013 - 99 papers.

The first thing, that came out from the preliminary study of ICA's papers, was that recent publishing record of the Association is rather poor (only 610 papers for 5 years), covering a very narrow area of the discussed topics. Most papers deal with disciplines which have traditionally belonged to the field of other professional organizations.

The preliminary study also revealed some confusion and uncertainty among ICA's members, caused by considerable progress in science and technology, which narrowed the field of their activity significantly. This can be easily traced by numerous subdivisions of research areas presented at ICA's Conferences. Moreover, it is necessary to point out that publishing activities of some of the commissions demonstrate clear tendencies of breaking down inter-disciplinary boundaries, making attempts to introduce new subjects into cartography.
Analysis of ICA's scientific interests enabled drawing a conclusion that most commissions provide summarization and transfer of existing knowledge and technologies that can be adopted in cartography. From our point of view, exceptions to this rule are only commissions 5, 6, 8 and 20 .

At the same time, since 2009 to 2013, we noted dynamic changes in the content of published papers, showing clear deviation from reviewing character to discussion of new trends and technologies that can be adopted in cartography.

When carrying out our further analysis we considered scientific activities of the following commissions: Cartography in Early Warning and Crisis Management, Cognitive Issues in Geographic Information Visualization, Generalization and Multiple Representation, and Planetary Cartography.

Based on the results of our analysis of the publications we marked out the most relevant topics in the field of development and use of advanced techniques, devices, tools, and software. The study of the topics allowed their grouping into nine subgroups, reflecting highest scientific and practical interests, see Table 2 .

\begin{tabular}{|r|l|c|}
\hline No & $\begin{array}{c}\text { Most popular subgroups of topics } \\
\text { brought up at ICA scientific events from } \\
\text { 2009 to 2013 }\end{array}$ & Percentage \\
\hline 1 & Automatic generalization of spatial data & 20.2 \\
2 & GIS applications & 15.2 \\
3 & Processing of high-resolution satellite & 15.2 \\
& imagery (data acquisition, analysis, & \\
& recognition and classification; & 14.1 \\
4 & visualization) & 8.1 \\
5 & Geospatial analysis & 8.1 \\
6 & Photogrammetry and remote sensing & 8.1 \\
7 & Spatial data infrastructure & 7.1 \\
8 & Multi-dimensional thematic mapping & 4.0 \\
\hline & Cartographic web applications and & services \\
9 & Spatial data quality & in the ICA publications 2009-2013 \\
\hline \multicolumn{2}{|c|}{ Table 2. Frequency of publications devoted to particular topics }
\end{tabular}

As we can see from Table 2 a notable part of the presented topics has never been in the ICA's field of study.

Figure 9 demonstrates those countries that made major contribution in publishing of advanced scientific papers at ICA's scientific events from 2009 to 2013.

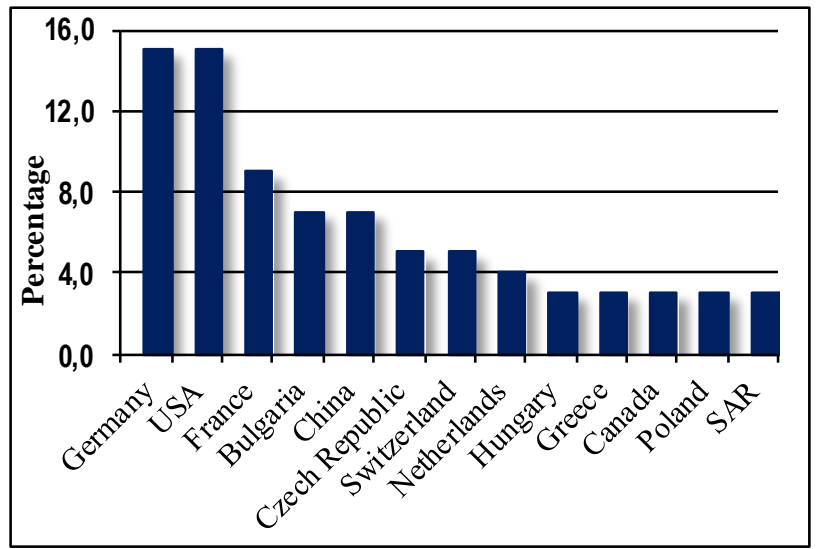

Figure 9. Countries that made major contribution in publishing advanced scientific papers at ICA International Cartographic Conferences 2009-2013 (percentage) 


\section{INTERNATIONAL SOCIETY FOR PHOTOGRAMMETRY AND REMOTE SENSING}

International Society for Photogrammetry was founded in 1910. In 1980 the Society was renamed into International Society for Photogrammetry and Remote Sensing. ISPRS is a nongovernmental organization devoted to the development of international cooperation for the advancement of remote sensing and photogrammetry together with their applications. The ISPRS's scientific interests include: photogrammetry, remote sensing, spatial information systems and related disciplines, as well as applications in cartography, geodesy, Earth and engineering sciences, environmental monitoring and protection, along with industrial design and manufacturing, objects of historical heritage preservation, medicine and so on.

The principal scientific activities of the Society are: initiating and coordinating research in photogrammetry and remote sensing; holding international symposia and congresses; ensuring worldwide circulation of the records of discussion and the results of research by publication of the International Archives of Photogrammetry and Remote Sensing; encouraging the publication and exchange of scientific papers and journals dealing with photogrammetry and remote sensing; promoting cooperation and coordination with related international scientific organizations.

Scientific activity of the Society is coordinated by its eight Technical commissions: Sensors and Platforms for Remote Sensing, Theory and Concepts of Spatial Information Science, Photogrammetric Computer Vision and Image Analysis, Geospatial Databases and Location Based Services, CloseRange Imaging, Analysis and Applications, Education, Technology Transfer and Capacity Development, Thematic Processing, Modeling and Analysis of Remotely Sensed Data, Remote Sensing Applications and Policies.

Unlike FIG the majority of ISPRS members represent scientific societies. From this point of view it was interesting to analyze modern trends in geospatial sciences and their relation to current practices.

Within our study we analyzed the ISPRS materials published at: - XXII ISPRS Congress (Volumes I-7), 2012, Melbourne, Australia

- The ISPRS Workshop on 3D Virtual City Modelling (Volume II-3/W1), 2013, Regina, Canada

- XXIV International CIPA Symposium (Volume II-5/W1), 2013, Strasbourg, France

- The ISPRS Workshop on Image Sequence Analysis 2013 (Volume II-3/W2), 2013, Antalya, Turkey

- ISA13 - ISPRS Workshop Laser Scanning 2013 (Volume II5/W2), 2013, Antalya, Turkey

- CMRT13 - City Models, Roads and Traffic 2013 (Volume II3/W3), 2013, Antalya, Turkey

- ISPRS 8th 3D GeoInfo Conference \& WG II/2 Workshop (Volume II-2/W1), 2013, Istanbul, Turkey

- ISPRS Acquisition and Modelling of Indoor and Enclosed Environments 2013 (Volume II-4/W1), 2013, Cape Town, South Africa

- ISPRS Technical Commission IV Symposium (Volume II-4), 2014, Suzhou, China

- ISPRS Technical Commission VI Symposium (Volume II-6), 2014, Wuhan, China

- ISPRS Technical Commission V Symposium (Volume II-5), 2014, Riva del Garda, Italy

- ISPRS Technical Commission III Symposium (Volume II-3), 2014, Zurich, Switzerland

- ISPRS Technical Commission VII Symposium (Volume II-7), 2014, Istanbul, Turkey
ISPRS Technical Commission II Symposium (Volume II-2), 2014, Toronto, Canada

ISPRS Technical Commission I Symposium (Volume II-1), 2014, Denver, Colorado, USA

- ISPRS Technical Commission VIII Symposium (Volume II8), 2014, Hyderabad, India.

Altogether, from 2012 to 2014,546 papers were analysed.

The results of our analysis of the materials published in 2012 we could mark out the most relevant topics brought up at ISPRS scientific events. The study of the topics permitted their grouping into eleven subgroups, reflecting highest scientific interests, see Table 3, and select the most active countries involved in research activities of the marked out subgroups, see Figures 10 - 15 .

\begin{tabular}{|r|l|c|}
\hline No & $\begin{array}{l}\text { Most popular topics brought up in ISPRS } \\
\text { papers 2012 }\end{array}$ & Percentage \\
\hline 1 & Remote sensing: algorithms and methods & 54.9 \\
2 & SAR, LiDAR, Radar & 6.8 \\
3 & Data bases: automatic acquisition, & 4.9 \\
& processing, storage, and updating of & \\
4 & spatial data & 0.5 \\
5 & UAV & 2.9 \\
6 & Spatial data infrastructure & 9.2 \\
7 & Mapping, geospatial services & 5.3 \\
8 & Virtual models, data visualisation & 7.3 \\
9 & Web applications and services & 2.4 \\
10 & environmental monitoring & 8.3 \\
11 & Point cloud processing & 2.4 \\
\hline
\end{tabular}

Table 3. Frequency of publications devoted to particular topics in the ISPRS materials 2012

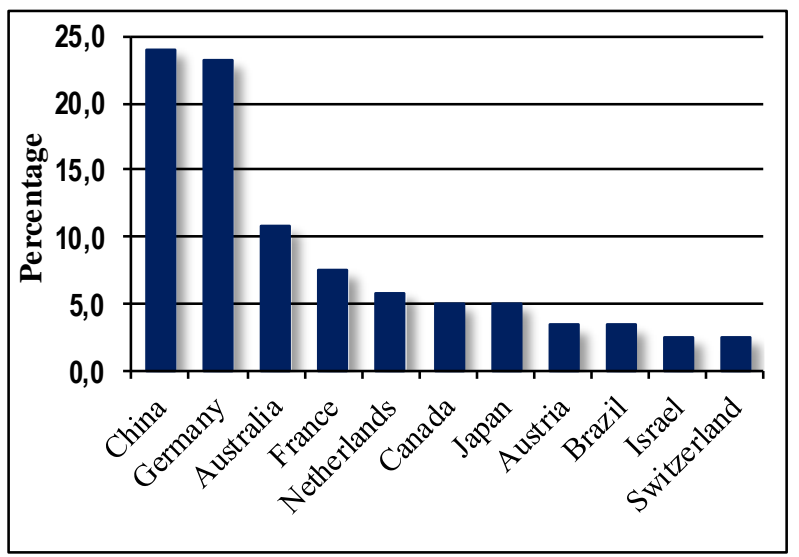

Figure 10. Countries that made major contribution in research related to Remote Sensing: algorithms and methods (2012)

The analysis of the published in 2012 papers allows making an assumption that scientists all over the world are interested in the search and development of new algorithms, methods and technologies of data acquisition (including automatic), analysis, processing, storage, exchange and updating into practitioners' everyday life activities.

First of all it concerns such activities as terrestrial and aerial laser scanning, usage of UAVs and services.

In comparison to 2012, in 2013-2014 a significant reduction of topical subdivision was noticed, see Table 4.

The analysis of papers for the period from 2013 to 2014 made it is possible to conclude that scientists, previously conducting their research in highly specialized fields, found common 
grounds with a number of inter-disciplinary matters dedicated to geospatial sciences.

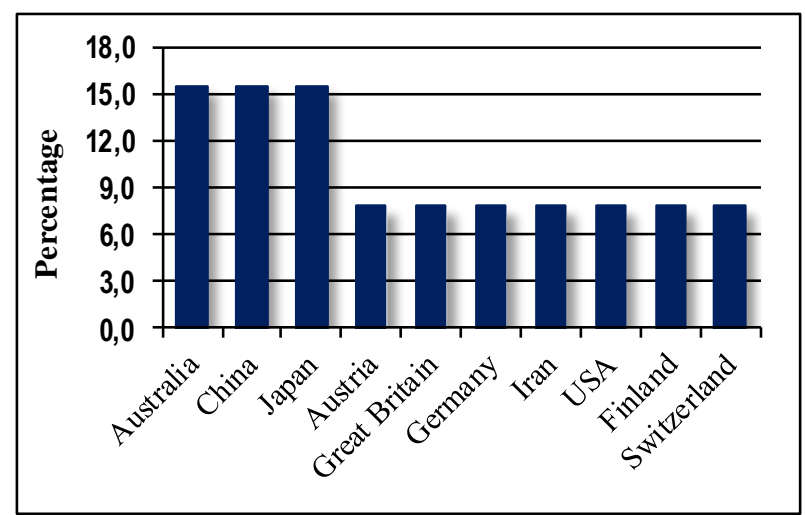

Figure 11. Countries that made major contribution in research related to Data bases: automatic acquisition, processing, storage and updating of spatial data (2012)

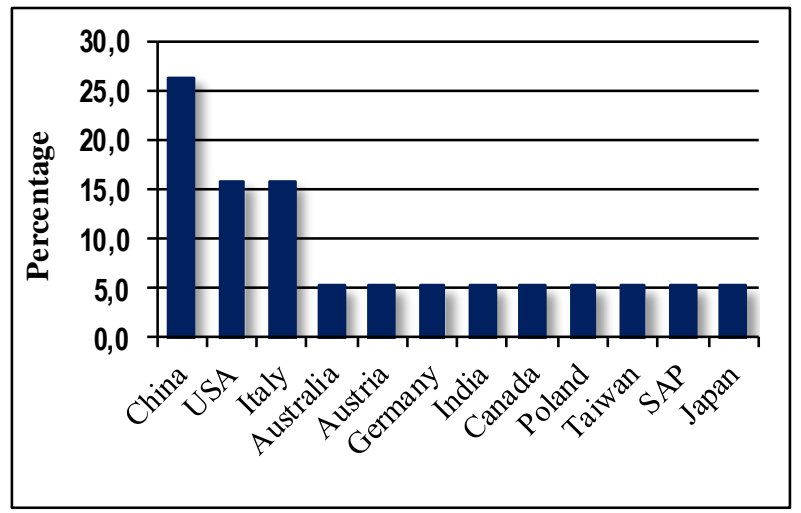

Figure 12. Countries that made major contribution in research related to web applications (2012)

The study of scientific activities, demonstrated at 2013-2014 ISPRS congresses, conferences, symposiums and workshops (altogether 484 papers) allows pointing out the leading countries that conduct their research at the cutting edge achievements in science and practices, see Figure 16.

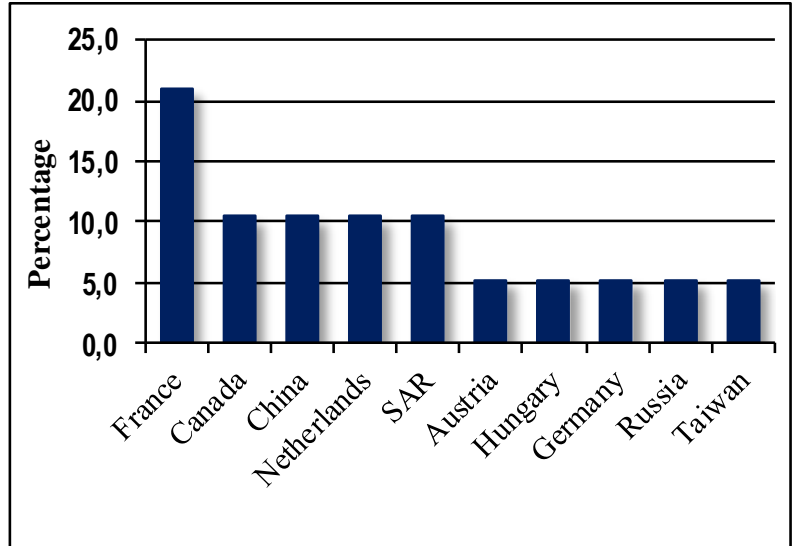

Figure 13. Countries that made major contribution in research related to point cloud processing (2012)

Thus, the results of our analysis on ISPRS 2013-2014 scientific activities, as well as target group surveys and interviews, allow us to make an assumption that in the nearest future the following trends will most probably take place in the development of geospatial sciences:

- Gradual replacement of LiDARs by photogrammetry when creating dense and exact DSMs

- LiDARs will keep their role for forest and transmission lines survey

- Creation of 3D city models will be done by photogrammetric survey

- There will be increase in use of 3D city models and textures (visualization, planning, measurements)

- It is possible there will be the increase of photogrammetric data processing for open-cast quarries

Increase of small aircraft and UAVs (payload 3-5 kilograms) usage for surveying objects, located in the areas outside of the city's limits

There will be further increase of UAV usage for aerial monitoring of linear objects

Further development and use of high-end medium format camera solutions, suitable for all kinds of photography

Significant development and usage of perspective aerial photography within city's limits

- Steady tendencies in the development of airborne multi- and hyperspectral imaging systems

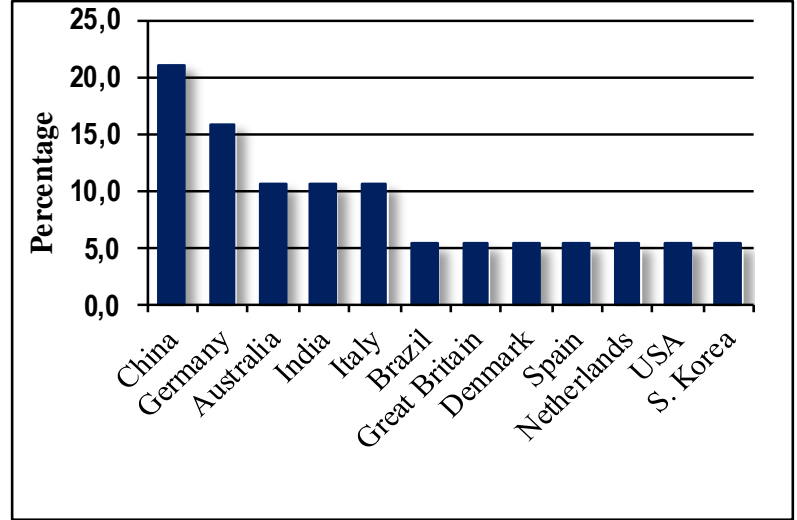

Figure 14. Countries that made major contribution in research related to mobile 2D and 3D mapping and development of spatial services (2012)

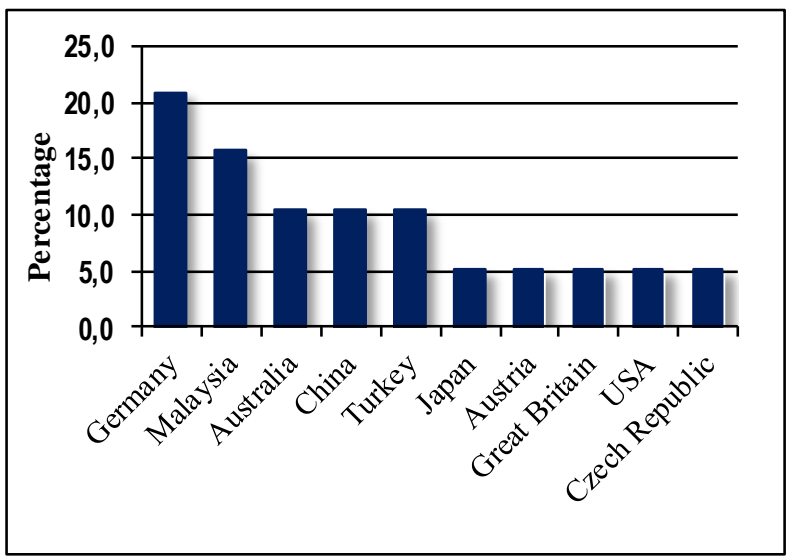

Figure 15. Countries that made major contribution in research related to usage of SAR / inSAR, LiDAR, and Radars in remote sensing (2012)

- A lot of research will be done to find solutions for large volume digital data processing, including aerial and satellite 
surveys (millions of square kilometers, short terms, high accuracy and quality)

- Development of new principles for data storage and fast availability Significant increase in speed and flexibility for updating of cartographic products.

\begin{tabular}{|c|c|c|}
\hline No & $\begin{array}{l}\text { Most popular subgroups of topics } \\
\text { brought up in ISPRS papers 2013-2014 }\end{array}$ & Percentage \\
\hline 1 & $\begin{array}{l}\text { Close-range imagery: analysis and } \\
\text { applications (classification, UAV, 3D } \\
\text { modelling, laser scanning, mobile laser } \\
\text { scanning, data stitching, self-calibration, } \\
\text { error analysis) }\end{array}$ & 28.6 \\
\hline 2 & $\begin{array}{l}\text { Photogrammetric computer vision and } \\
\text { image analysis (automatic recognition, } \\
\text { LiDAR, stereo camera, data stitching, } \\
\text { data extraction, data bases, algorithms, } \\
\text { DEM, terrestrial laser scanning, point } \\
\text { cloud, 3D mapping, GIS, calibration, } \\
\text { accuracy) }\end{array}$ & 22.2 \\
\hline 3 & $\begin{array}{l}\text { Remote sensing: sensors and platforms } \\
\text { (satellite imagery, modelling, infrared } \\
\text { survey, UAV, accuracy, point cloud, 3D } \\
\text { and mobile mapping, multispectral } \\
\text { imagery) }\end{array}$ & 12.8 \\
\hline 4 & $\begin{array}{l}\text { Thematic data processing, modelling and } \\
\text { remote sensing data analysis } \\
\text { (classification, change detection, SAR, } \\
\text { mapping point cloud, cluster analysis, } \\
\text { data acquisition, modelling) }\end{array}$ & 12.5 \\
\hline 5 & $\begin{array}{l}\text { Remote sensing data: development } \\
\text { strategies and applications (GIS, large } \\
\text { scale mapping, land use, statistics, } \\
\text { classification, monitoring, cadastral } \\
\text { maps, change detection, DEM, LiDAR, } \\
\text { health care, agriculture, water resources, } \\
\text { forestry, climate change) }\end{array}$ & 9.4 \\
\hline 6 & $\begin{array}{l}\text { Spatial data bases and services, web- } \\
\text { services }\end{array}$ & 8.4 \\
\hline 7 & $\begin{array}{l}\text { Theory and concepts of geospatial } \\
\text { sciences (cartography, DEM, 3D } \\
\text { modelling, GIS, data stitching } \\
\text { automation, LiDAR, 3D visualization, } \\
\text { software, algorithms, classification) }\end{array}$ & 6.1 \\
\hline
\end{tabular}

Table 4. Frequency of publications devoted to particular topics in the ISPRS materials 2013-2014

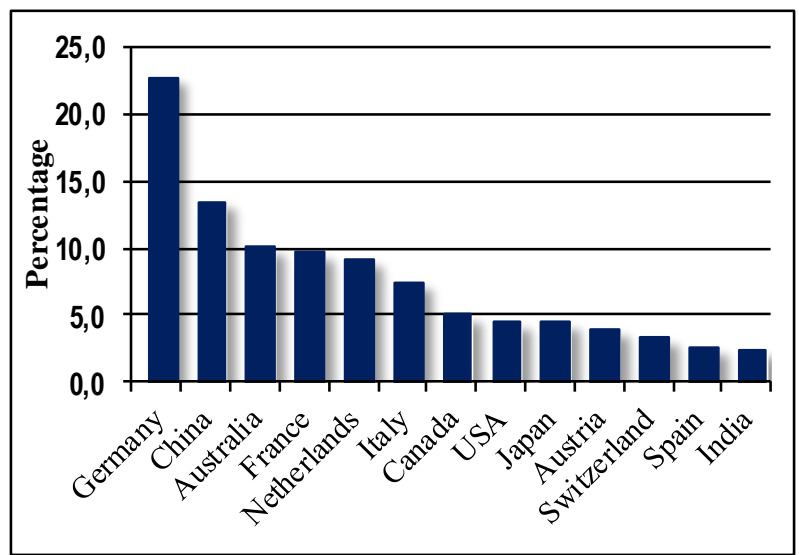

Figure 16. Countries that presented largest number of papers and reports at ISPRS scientific events in 2012-2014

\section{CONCLUSION}

Owing to the analysis of FIG, ICA, and ISPRS's scientific and practical activities it is possible to draw a general picture of those countries that are largely involved in work on topmost scientific domains lying in the area of interests of these organizations. Based on the results of our study we marked out ten leading countries making major contribution in research and implementation related to GS, see Figure 17.

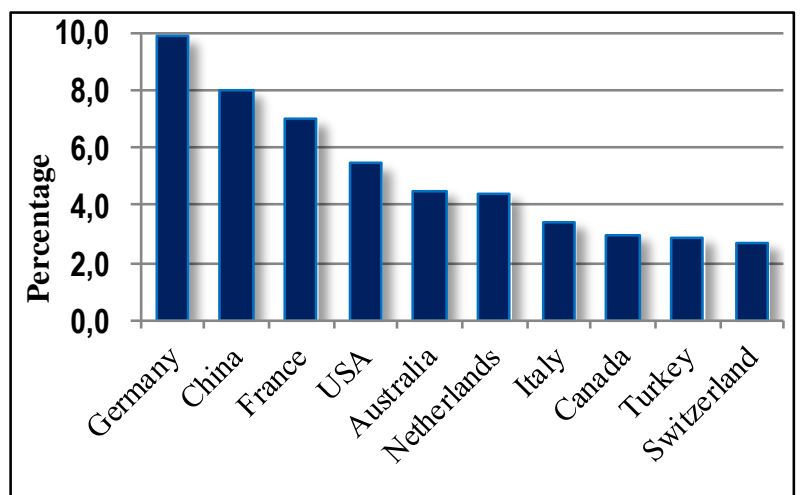

Figure 17. Top ten countries, making major contribution in research and implementation related to GS

From Figure 17 we can see that Germany and China are undisputable world leaders in conducting cutting edge research and practical implementation in fields related to GS. They are also in the top-five list of all of the studied organizations, which makes their experience interesting and needed to be properly studied. Special attention and deep analysis of innovation, research, practical implementation, as well as short and middle term planning must be paid to the activity of national agencies, research and development institutes, and professional organizations of such countries as Germany, China, France, USA, Australia, Netherlands, Italy, Canada, Turkey, and Switzerland.

The results of the study allow marking out the countries that can be considered as promising emerging GS markets for further cooperation, partnership, and joint implementation projects, see Table 5.

\begin{tabular}{|r|l|c|c|}
\hline No & Countries of emerging GS & Percentage & Place \\
\hline 1 & Narkets & & \\
2 & Russia, Japan & 2.5 & 11 \\
3 & Great Britain & 2.4 & $12-13$ \\
4 & Poland & 2.0 & 14 \\
5 & Brazil, Malaysia, Spain & 1.9 & 15 \\
6 & Greece, Finland & 1.4 & $19-18$ \\
7 & Chile & 1.3 & 21 \\
8 & Belgium & 1.2 & 22 \\
9 & Indonesia & 1.0 & 23 \\
10 & Austria, Israel, India, Sweden & 0.9 & $28-30$ \\
11 & Hungary, Czech Republic, & & \\
& New Zealand & 0.8 & $31-32$ \\
12 & Denmark, Iran & 0.7 & $33-36$ \\
13 & Bulgaria, South Korea South, & & \\
& African Republic, Croatia & 0.6 & $37-39$ \\
14 & Kenia, Portugal, Uruguay & 0.5 & 40 \\
15 & Argentina &
\end{tabular}

Table 5. Countries of emerging GS markets 


\section{ACKNOWLEDGEMENTS}

We thank our colleagues Yuri Raizman from VisionMap and Eugene Levin from Michigan Technological University who provided insight and expertise that greatly assisted the research, although they may not agree with all of the conclusions of this paper.

\section{REFERENCES}

FIG Congress 2014 in Kuala Lumpur, Malaysia 16-21 June 2014, http://www.fig.net/pub/fig2014/techprog.htm (24 Feb. 2015).

FIG Working Week 2013 in Abuja, Nigeria 6-10 May 2013, http://www.fig.net/pub/fig2013/techprog.htm (24 Feb. 2015)

FIG Working Week 2012 in Rome, Italy 6-10 May 2012, http://www.fig.net/pub/fig2012/techprog.htm (24 Feb. 2015).

8th FIG Regional Conference in Montevideo, Uruguay, 26 - 29 November 2012, http://www.fig.net/pub/171 ruguay/techprog.h tm (24 Feb. 2015).

24th International Cartographic Conference. The World's GeoSpatial Solutions, 15th to 21st of November, 2009, Santiago, Chile, http://icaci.org/files/documents/ICC_proceedings/ICC20 09/html/Programafull.pdf (28 Feb. 2015).

25th International Cartographic Conference. Paris, France, 3-8 July 2011, http://icaci.org/files/documents/ICC_proceedings/IC C2011/ (28 Feb. 2015).

26th International Cartographic Conference. August 25 - 30, 2013, Dresden, Germany, http://icaci.org/files/documents/ICC_ proceedings/ICC2013/ICC2013_program.pdf (28 Feb. 2015).

26th International Cartographic Conference. August 25 - 30, 2013, Dresden, Germany. Proceedings, http://icaci.org/files/doc uments/ICC_proceedings/ ICC2013/ICC2013_Proceedings.pdf (28 Feb. 2015).

Strategic plan for the International Cartographic Association 2011-2019, http://icaci.org/files/documents/reference_docs/ICA _Strategic_Plan_2011-2019.pdf (28 Feb. 2015).

XXII ISPRS Congress, Technical Commission VII (Volume I7), 25 August - 01 September 2012, Melbourne, Australia, http://www.isprs-ann-photogramm-remote-sens-spatial-infsci.net/I-7/\# (26 Feb. 2015).

XXII ISPRS Congress, Technical Commission IV (Volume I4), 25 August - 01 September 2012, Melbourne, Australia, http://www.isprs-ann-photogramm-remote-sens-spatial-infsci.net/I-4/ (26 Feb. 2015).

XXII ISPRS Congress, Technical Commission III (Volume I3), 25 August - 01 September 2012, Melbourne, Australia, http://www.isprs-ann-photogramm-remote-sens-spatial-infsci.net/I-3/ (26 Feb. 2015).

XXII ISPRS Congress, Technical Commission II (Volume I-2), 25 August - 01 September 2012, Melbourne, Australia, http://www.isprs-ann-photogramm-remote-sens-spatial-infsci.net/I-2/ (26 Feb. 2015).

The ISPRS Workshop on 3D Virtual City Modeling (Volume II-3/W1), 28 May 2013, Regina, Canada, http://www.isprs-annphotogramm-remote-sens-spatial-inf-sci.net/II-3-W1/index.html (26 Feb. 2015).
XXIV International CIPA Symposium (Volume II-5/W1), 2-6 September 2013, Strasbourg, France, http://www.isprs-annphotogramm-remote-sens-spatial-inf-sci.net/II-5-W1/index.html (26 Feb. 2015).

The ISPRS Workshop on Image Sequence Analysis 2013 (Volume II-3/W2), 11 November 2013, Antalya, Turkey, http://www.isprs-ann-photogramm-remote-sens-spatial-infsci.net/II-3-W2/index.html (26 Feb. 2015).

ISA13 - ISPRS Workshop Laser Scanning 2013 (Volume II5/W2), 11-13 November 2013, Antalya, Turkey, http://www.isprs-ann-photogramm-remote-sens-spatial-infsci.net/II-5-W2/index.html (26 Feb. 2015).

CMRT13 - City Models, Roads and Traffic 2013 (Volume II3/W3), 12-13 November 2013, Antalya, Turkey, http://www.isprs-ann-photogramm-remote-sens-spatial-infsci.net/II-3-W3/index.html (26 Feb. 2015).

ISPRS 8th 3D GeoInfo Conference \& WG II/2 Workshop (Volume II-2/W1), 27-29 November 2013, Istanbul, Turkey, http://www.isprs-ann-photogramm-remote-sens-spatial-infsci.net/II-2-W1/index.html (26 Feb. 2015).

ISPRS Acquisition and Modelling of Indoor and Enclosed Environments 2013 (Volume II-4/W1), 11-13 December 2013, Cape Town, South Africa, http://www.isprs-ann-photogrammremote-sens-spatial-inf-sci.net/II-4-W1/index.html $\quad(26$ Feb. 2015).

ISPRS Technical Commission IV Symposium (Volume II-4), 14-16 May 2014, Suzhou, China, http://www.isprs-annphotogramm-remote-sens-spatial-inf-sci.net/II-4/index.html (26 Feb. 2015).

ISPRS Technical Commission VI Symposium (Volume II-6), 19-21 May 2014, Wuhan, China, http://www.isprs-annphotogramm-remote-sens-spatial-inf-sci.net/II-6/index.html (26 Feb. 2015).

ISPRS Technical Commission V Symposium (Volume II-5), 23-25 June 2014, Riva del Garda, Italy, http://www.isprs-annphotogramm-remote-sens-spatial-inf-sci.net/II-5/index.html (26 Feb. 2015).

ISPRS Technical Commission III Symposium (Volume II-3), 5-7 September 2014, Zurich, Switzerland, http://www.isprsann-photogramm-remote-sens-spatial-inf-sci.net/II-3/index.html (26 Feb. 2015).

ISPRS Technical Commission VII Symposium (Volume II-7), 29 September-2 October 2014, Istanbul, Turkey, http://www.isprs-ann-photogramm-remote-sens-spatial-infsci.net/II-7/index.html (26 Feb. 2015).

ISPRS Technical Commission II Symposium (Volume II-2), 68 October 2014, Toronto, Canada, http://www.isprs-annphotogramm-remote-sens-spatial-inf-sci.net/II-2/index.html (26 Feb. 2015).

ISPRS Technical Commission I Symposium (Volume II-1), 17 20 November 2014, Denver, Colorado, USA, http://www.isprsann-photogramm-remote-sens-spatial-inf-sci.net/II-1/index.html (26 Feb. 2015).

ISPRS Technical Commission VIII Symposium (Volume II-8), 09-12 December 2014, Hyderabad, India, http://www.isprsann-photogramm-remote-sens-spatial-inf-sci.net/II-8/index.html (26 Feb. 2015). 